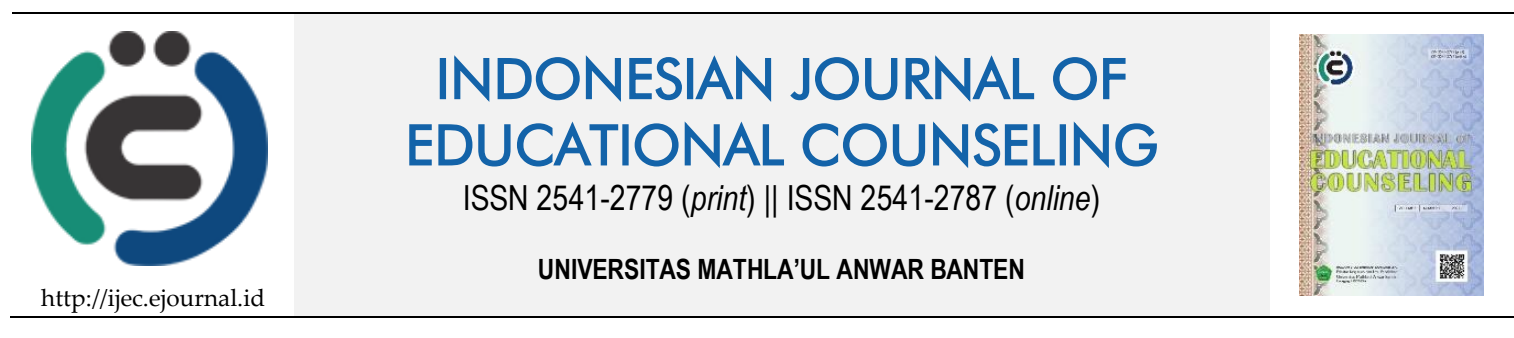

Research Based Article

\title{
Pengembangan Modul Pencegahan Penyalahgunaan NAPZA untuk Meningkatkan Pengetahuan Pencegahan bagi Siswa SMP di Jakarta Timur
}

\author{
Ahmad Rifqy Ash-Shiddiqy ${ }^{1}$, Happy Karlina Marjo², Michiko Mamesah², \\ Hilma Fitriyani ${ }^{2}$ \\ 1,2 Universitas Negeri Jakarta, Indonesia
}

\begin{tabular}{ll}
\hline Article History & ABSTRACT \\
\hline Received: 26.11.2020 & DEVELOPMENT OF A DRUG ABUSE PREVENTION MODULE TO \\
Received in revised form: & INCREASE PREVENTION KNOWLEDGE FOR JUNIOR HIGH SCHOOL \\
Accepted: 07.01 .2021 & STUDENTS IN EAST JAKARTA. The aim of this study was to determine the \\
Available online: 29.01.2021 & effectiveness of the implementation of the drug abuse prevention module \\
& development in increasing prevention knowledge for students at the junior \\
& high school level in East Jakarta. The research method used was educational \\
& design research research method with the development model Design by \\
& Research. In this method there are 3 main phases, namely the analysis and \\
& exploration phase, the design and development phase, and the evaluation and \\
& reflection phase. The samples in this study were Guidance and Counseling \\
& teachers in East Jakarta Junior High Schools who became partners of the \\
& Guidance and Counseling Study Program of FIP UNJ. The development of a \\
& drug abuse prevention module in East Jakarta Junior High School focuses on \\
& (1) knowledge that students must know, (2) attitudes and values, and (3) skills. \\
& The results showed that the module was in accordance with the students' goals, \\
the material was considered appropriate, although it still needed to be \\
improved in terms of the delivery method and the media completeness needed \\
to deliver the material in the module. Modules can also help optimize peer \\
groups as a classical mentoring service to build drug-free youth. Based on the \\
results of this study, it can be concluded that the development of a drug abuse \\
prevention module is effective in increasing prevention knowledge for students \\
at the junior high school level in East Jakarta.
\end{tabular}

KEYWORDS: Classical Guidance, Counseling Guidance, Drugs.

DOI: $10.30653 / 001.202151 .152$

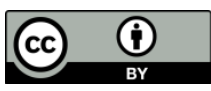

This is an open access article distributed under the terms of the Creative Commons Attribution 4.0 International License, which permits unrestricted use, distribution, and reproduction in any medium, provided the original work is properly cited. ○ 2021 Ahmad Rifqy Ash-Shiddiqy, Happy Karlina Marjo, Michiko Mamesah, Hilma Fitriyani.

\section{PENDAHULUAN}

Remaja merupakan kelompok yang rentan dalam hal penyalahgunaan NAPZA. Hal ini dijelaskan oleh National Institute on Drug Abuse (2014) bahwa masa remaja merupakan masa yang rentan untuk penyalahgunaan NAPZA yang disebabkan oleh sulitnya masa

\footnotetext{
${ }^{1}$ Corresponding author's address: Program Studi Bimbingan dan Konseling, Universitas Negeri Jakarta. Jl. Rawamangun Muka, RT.11/RW.14 Rawamangun, Kec. Pulo Gadung, Kota Jakarta Timur, DKI Jakarta 13220, Indonesia; Email: ahmadrifqy @unj.ac.ic
} 
transisi yang dihadapi dan juga keinginan yang besar untuk diterima oleh kelompok. Penggunaan NAPZA seringkali diyakini akan membantu individu untuk terlihat lebih keren, mengukur tingkat solidaritas, merasa hebat, mengurangi rasa sakit, stress, rasa bosan, serta menghasilkan tantangan dan menampilkan kedewasaan (Amanda, et.al., 2017). Mitos ini tentu sangat memungkinkan membuat remaja mengambil keputusan untuk menggunakan Napza dalam rangka membantu masa transisinya yang sulit.

Dampak yang ditimbulkan oleh penyalahgunaan NAPZA sangat besar dan mempengaruhi individu dalam menjalankan berbagai tugas perkembangan kehidupannya. National Institute on Drug Abuse (2014) menjelaskan bahwa penyalahgunaan NAPZA pada masa remaja dapat merusak fungsi otak pada bagian penting terkait motivasi, belajar, pengambilan keputusan, dan kontrol tingkah laku sehingga para remaja yang menggunakan alkohol atau jenis zat lainnya seringkali memiliki masalah keluarga dan sosial, pencapaian hasil akademik yang rendah, serta terlibat dalam kenakalan remaja. Dampak besar yang ditimbulkan dari penyalahgunaan NAPZA perlu ditindaklanjuti dengan membantu berbagai pihak, seperti orangtua, masyarakat dan pihak sekolah dalam hal ini guru Bimbingan dan Konseling untuk melakukan upaya preventif dan kuratif. Dalam rangka membantu guru Bimbingan dan Konseling perlu dilakukan upaya kolaboratif dan sinergitas dengan berbagai pihak. Salah satu upaya yang dapat dilakukan untuk mendukung hal tersebut adalah melalui penyediaan bahan ajar berupa modul yang dapat digunakan oleh para guru BK dalam memberikan layanan dasar.

Hasil-hasil penelitian menunjukkan bahwa penggunaan modul mampu meningkatkan pencapaian hasil belajar pada peserta didik. Penelitian yang dilakukan oleh Aryani (2017) memperlihatkan bahwa modul memberi pengaruh terhadap hasil belajar, dimana hasil belajar kognitif peserta didik meningkat dari sebelum penerapan modul pembelajaran dengan setelah penerapan modul pembelajaran. Peningkatan hasil belajar secara kognitif akan berdampak terhadap pembentukan sikap. Adapun hasil penelitian yang dilakukan oleh Fadhillah, et.al. (2015) bahwa terdapat hubungan yang signifikan antara pemahaman tentang NAPZA dengan sikap penolakan penyalahgunaan NAPZA pada siswa kelas VIII SMP Negeri se-Kecamatan Johar Baru, Jakarta Pusat. Implikasi dari hasil penelitian ini ditujukan kepada guru BK untuk dapat memberikan informasi mengenai NAPZA sebagai upaya pencegahan penyalahgunaan NAPZA berupa pemberian materi bimbingan klasikal dan pengadaan layanan bimbingan kelompok. Hasil kajian yang dilakukan oleh Mamesah, et.al. (2019) terhadap modul terkait NAPZA di 10 sekolah mitra Praktik Keterampilan Mengajar (PKM) Prodi Bimbingan dan Konseling Universitas Negeri Jakarta menunjukkan bahwa materi-materi yang ada pada modul yang tersedia saat ini tidak cukup komprehensif, antara lain belum memuat dasar hukum terbaru, upaya treatment yang dapat dilakukan, dampak NAPZA secara lebih komprehensif (sosial, emosional, kognisi dan fisik).

\section{METODE}

Metode penelitian yang digunakan adalah metode penelitian educational design research dengan model pengembangan Design by Research yang dikembangkan oleh Susan McKenney dan Thomas C. Reeves. Pengembangan desain dalam model penelitian ini melewati 3 fase utama, yaitu fase analysis and exploration (analisis dan eksplorasi), fase design and development (desain dan pengembangan), dan fase evaluation and reflection (evaluasi dan refleksi). 
Pengumpulan data dilakukan dengan memberikan instrumen penilaian kepada para guru yang bersedia untuk memberikan penilaian pada produk yang dikembangkan dalam penelitian ini. Analisis data dilakukan dengan mempersiapkan norma penilaian dari instrumen penilaian yang diisi oleh responden penelitian terkait dengan penilaian terhadap kualitas modul secara konten dan juga tampilan. Perhitungan menggunakan skor maksimal dan minimal serta dibagi ke dalam empat kategori penilaian (sangat kurang, kurang, baik, dan sangat baik). Selain analisis secara kuantitatif, penilaian kualitatif dari para responden penelitian selaku evaluator produk yang dikembangkan dalam penelitian ini juga akan dianalisis.

\section{HASIL DAN PEMBAHASAN}

Narkoba (narkotika, psikotropika dan bahan-bahan zat adiktif lainnya) dapat membahayakan kehidupan manusia, jika dikonsumsi dengan cara yang tidak tepat, bahkan dapat menyebabkan kematian. Narkoba mempunyai dampak negatif yang sangat luas; baik secara fisik, psikis, ekonomi, sosial budaya hankam, dan lain sebagainya. Orang menggunakan zat narkoba untuk memenuhi kebutuhan atau tujuan tertentu. Narkoba dapat memenuhi kebutuhan atau keinginan tertentu melalui efeknya (termasuk penghilang rasa sakit dan perasaan menyenangkan) atau melalui simbolisme yang terkait dengan penggunaannya (misalnya, rasa pemberontakan atau perasaan saling memiliki). Semua keputusan penggunaan zat melibatkan penimbangan manfaat terhadap risiko yang dirasakan oleh individu. Remaja menggunakan zat narkoba untuk banyak alasan yang sama yang dilakukan orang dewasa (untuk menghilangkan stres atau meningkatkan kenikmatan). Namun, ada beberapa alasan penggunaan yang muncul dari kebutuhan khusus terkait dengan perkembangan remaja. Sumber motivasinya yaitu keinginan untuk mengambil risiko, menunjukkan otonomi dan kemandirian, mengembangkan nilai-nilai yang berbeda dari otoritas orang tua dan masyarakat, memberi isyarat masuk ke dalam kelompok sebaya, mencari pengalaman baru dan menarik, serta memuaskan rasa ingin tahu (Evans \& Bosworth 1997).

Bagi remaja, peer group merupakan kelompok penting sehingga hal ini juga dapat dimanfaatkan untuk memberikan intervensi terhadap pencegahan penggunaan narkoba kepada mereka. Menurut Hurlock (2000), pengaruh teman sebaya (peer group) sangat besar selama masa remaja dan lebih dominan pengaruhnya dibandingkan dengan pengaruh keluarga. Menurut teori ekologi Bronfenbrenner, teman sebaya merupakan bagian dari mikrosistem remaja. Dalam teori ekologi menyatakan bahwa lingkungan memiliki pengaruh yang besar dalam perkembangan seseorang pada level mikrosistem ini hubungan dan interaksi individu dengan lingkungan terdekat di sekelilingnya, termasuk teman sebaya akan sangat mempengaruhi perkembangannya (Santrock, 1999).

Pada pergaulan remaja pemakai narkoba, jika ada salah satu diantara temannya yang tidak mengkonsumsi narkoba maka akan mendapatkan perlakuan yang kurang baik dari temannya seperti dimusuhi atau diejek (Aini \& Rangkuti, 2014). Maka begitu pula jika di lingkungan peer group terdapat teman dominan yang memiliki nilai untuk menolak terhadap penggunaan narkoba, maka lama-kelamaan itu akan menjadi nilai yang dipegang bersama oleh seluruh anggota peer group. Oleh karena itu peer group melalui layanan bimbingan klasikal dapat dimanfaatkan untuk menyebarkan virus positif termasuk sebagai pervention agent dalam upaya mencegah remaja terlibat dalam penyalahgunaan narkoba. 
Upaya menanggulangi permasalahan pemakaian zat adiktif/narkoba ditujukan sesuai dengan tahapan kontinum pemakaian zat itu sendiri. Terdapat konsep pencegahan, mulai dari primer, sekunder dan tersier yang dapat diterapkan pada penyakit ini. Pencegahan primer adalah mencegah seseorang yang sebelumnya tidak memakai zat adiktif untuk tidak mencoba atau memakai teratur. Pencegahan sekunder adalah mencegah seseorang yang sudah menggunakan agar tidak masuk ke dalam kelompok berisiko dan tidak menjadi tergantung atau adiksi. Pencegahan tersier adalah mereduksi bahaya yang timbul dari masalah-masalah penyalah guna narkoba dan adiksi termasuk tindakan terapi dan rehabilitasi sampai seminimal mungkin menggunakannya atau bahkan tidak menggunakan sama sekali (Hamilton, et.al. dalam Prasetyo dan Utami, 2014).

Fadhillah (2015) mengemukakan bahwa pengetahuan yang dimiliki peserta didik terhadap NAPZA akan berhubungan dengan sikap untuk menolak penyalahgunaan NAPZA. Mengingat pengetahuan akan NAPZA berkorelasi erat dengan sikap individu terhadap penolakan pencegahan NAPZA, maka diperlukan media belajar yang dapat membantu peningkatan hasil belajar. Modul adalah media yang dapat dipilih mengingat sifatnya yang komprehensif. Menurut Purwanto (2007) modul ialah bahan belajar yang dirancang secara sistematik berdasarkan kurikulum tertentu dan dikemas dalam bentuk satuan pembelajaran terkecil dan memungkinkan dipelajari secara mandiri dalam satuan waktu tertentu. Tujuannya agar peserta dapat menguasai kompetensi yang diajarkan dalam diklat atau kegiatan pembelajaran dengan sebaik-baiknya. Fungsinya sebagai bahan belajar yang digunakan dalam kegiatan pembelajaran peserta didik. Modul merupakan jenis kesatuan kegiatan belajar yang terencana, dirancang untuk membantu pada para peserta didik secara individual dalam mencapai tujuan-tujuan belajarnya. Modul bisa dipandang sebagai paket program pengajaran yang terdiri dari komponenkomponen yang berisi tujuan belajar, bahan ajar, metode belajar, alat atau media, serta sumber belajar dan sistem evaluasinya.

Modul yang disusun diharapkan memberikan pengetahuan yang memadai bagi siswa untuk dapat memiliki sikap mampu melakukan pencegahan terhadap penyalahgunaan NAPZA. Beberapa hal yang perlu diperhatikan dalam rangka menyiapkan upaya pencegahan adalah bahwa dalam upaya pencegahan harus terdapat kombinasi yang mengembangkan pengetahuan, sikap, dan keterampilan dengan kontenkonten yang berisikan upaya meningkatkan kesehatan, pengembangan harga diri (selfesteem), dan peningkatan keterampilan untuk melakukan penolakan (resistance skills) misalnya dalam bentuk keterampilan komunikasi dan membangun hubungan yang sehat dengan teman sebaya. Strategi yang digunakan juga perlu ditujukan untuk mendorong pengembangan kekuatan individu dan hal-hal yang dapat memberikan perlindungan individu dalam situasi dan lingkungan yang penuh tekanan (UN, 2002).

Hasil Penelitian menunjukkan bahwa modul sesuai dengan sasaran peserta didik, materi dianggap sesuai meskipun masih perlu diperbaiki dalam hal metode penyampaiannya dan kelengkapan media yang diperlukan untuk penyampaian materi di dalam modul. Modul juga dapat membantu mengoptimalkan peer group sebagai layanan bimbingan klasikal untuk membangun remaja bebas narkoba.

\section{SIMPULAN}

Berdasarkan hasil penelitian yang dilakukan, maka dapat disimpulkan bahwa pengembangan modul pencegahan penyalahgunaan NAPZA di SMP Jakarta Timur 
ditinjau dari aspek pengetahuan yang harus diketahui siswa, sikap dan nilai-nilai, serta keterampilan dapat digunakan oleh guru sebagai modul dalam layanan bimbingan klasikal untuk meningkatkan pengetahuan pencegahan penyalahgunaan NAPZA pada Sekolah Menengah Pertama Mitra Praktikum Keterampilan Mengajar Prodi Bimbingan Konseling Universitas Negeri Jakarta.

Adapun saran-saran dalam penelitian ini adalah 1) menjadi referensi untuk Modul Pencegahan Penyalahgunaan NAPZA dalam layanan bimbingan klasikal untuk neningkatkan pengetahuan pencegahan penyalahgunaan NAPZA pada sekolah menengah pertama; 2) melaksanakan pelatihan dalam rangka kesiapan mahasiswa UNJ menghadapi dunia kerja yang diselenggarakan sebagai guru Bimbingan dan Konseling untuk menggunakan Modul Pencegahan Penyalahgunaan NAPZA dalam layanan bimbingan klasikal untuk meningkatkan pengetahuan pencegahan penyalahgunaan NAPZA pada sekolah menengah pertama; serta 3) bekerjasama dengan BNN dalam membantu memberikan layanan berbasis NAPZA.

\section{REFERENSI}

Aryani, I. (2017). Efektivitas Penggunaan Modul Pembelajaran Pada Mata Kuliah Ekologi Hewan Materi Populasi Hewan: Universitas Muhammadiyah Surakarta Seminar Nasional Pendidikan Sains II UKSW, 41-47.

Fadhillah, N., Setyowati, E., \& Tjalla, A. (2015). Hubungan pemahaman NAPZA dengan sikap terhadap penyalahgunaan NAPZA (Studi korelasi pada siswa kelas VIII SMP Negeri Se-Kecamatan Johar Baru). Insight: Jurnal Bimbingan dan Konseling, 4(1), 1-6.

National Institute of Drug Abuse. (2014). Drugs, brain and behavior. Maryland: National Institute of Drug Abuse.

Prasetyo, S., \& Utami, D.S. (2014). Prevensi sekunder pemakaian zat adiktif. Buletin Jendela Data dan Informasi Kesehatan, 1, 23-28.

Purwanto, Rahadi, A., \& Lasmono, S. (2007). Pengembangan modul. Jakarta: Pusat Teknologi Informasi dan Komunikasi Pendidikan Departemen Pendidikan Nasional.

United Nation. (2002). A Participatory handbook for youth drug abuse prevention programmes: A Guide for development and improvement. Vienna: United Nations Office for Drug Control and Crime Prevention. 